\title{
PSICANÁLISE E ESTÉTICA DA RECEPÇÃO: DESACORDOS E ENTRECRUZAMENTOS*
}

Gustavo Henrique Dionisio

Gustavo Henrique

Dionisio

Professor-

assistente doutor

da Universidade

Estadual Paulista

(Unesp),

Departamento de Psicologia Clínica.
RESUMO: Este trabalho visa discutir entrecruzamentos e dessemelhanças entre a teoria da recepção estética da escola de Jauss, Iser e colaboradores, e a psicanálise freudiana. Os teóricos da recepção estética leram Freud, o que não significa dizer que compreenderam suas posições com relação à leitura da obra de arte. Assim, o ensaio almeja sistematizar algumas das vicissitudes desta relação.

Palavras-chave: Recepção estética, psicanálise, catarse, mecanismos de defesa, identificação.

ABSTRACT: Psychoanalysis and Aesthetics Reception: disagreements and crosslinkings. This paper aims to discuss certain intersections and discrepancies between the theories of aesthetic reception, as we can see in Jauss and Iser writings, and Freudian psychoanalysis. As we know, the theorists of the aesthetic reception read Freud, but that doesn't mean that the authors have well understood their positions related to the reading action of the artwork. Thus, this work intends to describe some of this relationship features.

Keywords: Aesthetics reception, psychoanalysis, catharsis, defense mechanisms, identification.

\footnotetext{
* Este artigo é fruto de pesquisa de doutoramento pelo Instituto de Psicologia da USP e se articula à pesquisa atual desenvolvida no Departamento de Psicologia Clínica da FCL-Unesp Assis.
} 


\section{INTRODUÇÃO}

A maioria das investidas que os psicanalistas direcionam ao campo mais amplo da arte e da cultura se resume, sem dúvida, à literatura. A vontade de se debruçar sobre os textos literários é certamente quem puxa o carro-chefe das investigações que se lançam a esta dimensão "extraclínica" - por falta de expressão mais adequada - da psicanálise. Além do caráter mais "psicologicamente explícito” do material literário, para grande parte dos psicanalistas o escritor seria aquele sobre quem recai uma liberdade de escolha de assuntos e temas que não é ofertada, de outro lado, aos artistas visuais. O "preço da incerteza de sua vida material", afirma a esse respeito Germain Bazin, "não correspondia ao modo de operar da arte de outrora" (1989), ou seja: uma arte regulada basicamente pelo sistema da encomenda. Isto não eximiria, ainda segundo o autor, certos psicanalistas (e tampouco os historiadores) de terem se apropriado de uma série de mal-entendidos. Um dos exemplos mais patentes é a atribuição de uma repetição de determinado tema a um artista que, a bem da verdade, não o havia escolhido mas apenas o executado, dado que era um costume frequente das escolas de formação, anteriores ao advento da Arte Moderna.

Ora, problemas desta ordem corroboram a pertinência de análises de cunho histórico-textual, tais como as da Estética da Recepção. Com efeito, na Escola de Constança - como é conhecida ainda hoje - certos pesquisadores empregaram o método "imanentista" na leitura da obra, o que dificultaria a ocorrência de contradições como aquelas citadas antes. Em termos discursivos, a grande questão indicada pelos pesquisadores se resumiria a o "que significa ao espectador, em termos puramente objetivos, a experiência estética”? Assim, este trabalho pretende discutir a relação entre Psicanálise e Estética da Recepção, tendo em vista algumas de suas congruências, sem deixar de lado certos desacordos que aí surgirão. Nesse sentido, a reflexão deve passar, obrigatoriamente, por questões que tangenciam os dois campos: entram em jogo problemas que vão da catarse à empatia, assim como os mecanismos de identificação e projeção que a ambos atravessam. A meu ver, e na medida de seu recorte, o percurso permitiria questionar a tese reducionista de que o prazer estético se encerra no retorno do recalcado, além de auxiliar-nos a refletir sobre o limite das interpretações que convergem invariavelmente no Complexo de Édipo sem questionar suas consequências fundamentais.

\section{ESTUDOS DE RECEPÇÃO ESTÉTICA}

De acordo com Hans Robert Jauss (1991), um de seus principais articuladores, quando lançamos o olhar a um determinado objeto, quando ouvimos uma canção ou lemos um poema, estamos colocando em funcionamento duas condições 
sensíveis essenciais: agindo dialeticamente, "fruição compreensiva" e "compreensão fruidora" são os estados cognitivos primários do processo de recepção, aos quais será acrescida, a seguir, a complexa demanda de um “ato reflexivo”, segundo as palavras de Wolfgang Iser, outro autor iminente neste contexto.

Mais especificamente falando, Jauss concebe de antemão que recepção não é um sinônimo para o efeito estético: se na recepção o condicionamento da leitura se realiza no destinatário, no efeito o que surge como determinante é o texto, a obra em si mesma. Em síntese, o efeito, que alude a relações com o passado, se distinguiria da recepção porque esta depende de um "destinatário ativo e livre, que, julgando de acordo com as normas estéticas de seu tempo, modifica, pela sua existência presente, os termos do diálogo" (STAROBINSKI, 1991, p.19). A análise não pode se desviar dos meios ideológicos sob os quais a obra foi concebida, assim como deve se ater ao consumo e historicidade nela concorrentes. Para Jauss e Iser, o espectador de arte tem uma função e um lugar específicos no mecanismo de produção; e ainda que a estrutura da obra não seja reduzida à sua recepção, a história da arte depende da existência de um destinatário. Com isso, o imperativo da contextualização não exerce função de fundo, mas de figura, e é a união exata entre esses elementos que assegura o que podemos chamar de experiência estética. "O prazer estético que, desta forma" - pelo prazer de si no outro —, "se realiza na oscilação entre a contemplação desinteressada e a participação experimentadora”, escreve a esse respeito Jauss, “é um modo da experiência de si mesmo na capacidade de ser outro, capacidade a nós aberta pelo comportamento estético" (1979b, p.77).

Por essa razão, a estética da recepção seria, mutatis mutandis, uma fenomenologia da experiência com a arte. Enquanto ciência parcial, deve recortar e aprofundar o questionamento acerca da produção, reprodução e consumo de arte. São estes os pressupostos que definem o trabalho do leitor: segundo Iser, o exercício de recepção consiste em trazer à tona os dizeres concretos do texto. Em outras palavras, trata-se de "realizá-lo", um ato de Konkretisation (Ingarden). Ora, existe sempre algo de implícito na obra de arte: todo texto/imagem tem o mérito de apresentar tanto as questões quanto as próprias respostas cuja virtualidade de sentido está à espera de ser concretizada pela recepção. O "trabalho literário possui dois polos”, escreve Iser, “aos quais podemos chamar de artístico e de estético: o artístico se refere ao texto criado pelo autor, e o estético à realização efetuada pelo leitor” (1990, p.274). Por conseguinte, o "trabalho literário” não é idêntico ao texto ou à leitura: ele está a meio caminho entre os dois.

A convergência entre leitor e texto dá margem ao mundo virtual que é a obra de arte. No entanto, este espaço intermediário criado entre eles não deve ser identificado, simplesmente, com "a realidade do texto ou com a disposição individual do leitor” (ISER, 1990, p.275). Segundo o teórico alemão, 
“Assim como o leitor usa as várias perspectivas oferecidas a ele, pelo texto, de modo a relacionar os padrões e as "visões esquematizadas" entre si, ele coloca o texto em movimento, e esse processo resulta finalmente num despertar de respostas internas. Portanto, ler faz como que o trabalho literário desdobre seu próprio caráter dinâmico.” (idem)

Em meio ao adensamento "quente" do textual residem elementos não escritos que desejam participação ativa, demandando uma posição criativa por parte do espectador. Na visão de Iser, além de atraírem o leitor, os aspectos não apresentados pela superfície do texto seduzem-no a completar as entrelinhas, construindo assim uma realidade textual particular. Dado o convite, o espectador se vê diante da responsabilidade de manejar o processo vivo da interpretação. Por outro lado, o texto também aceita seus próprios encargos, de modo a impor certos limites às implicações não escritas "com a finalidade de preveni-las de se tornarem muito embaçadas e enevoadas". Mas conforme as implicações vão sendo "trabalhadas pela imaginação do leitor” (ISER, 1990, p.276), elas aumentam o universo da significação linguageira de modo considerável.

Para os teóricos de Constança, a leitura de cunho psicológico, que em geral recai no método psicanalítico, em princípio deve ser rejeitada em nome da análise fenomenológica. A título de exemplo, as interpretações psicanalíticas conviriam apenas à ilustração de "ideias predeterminadas respectivas ao inconsciente" (ISER, 1990), de modo que não compõem, ainda segundo Iser, análises que partam diretamente do objeto.

Deixando a leitura psicológica de lado, o pressuposto da estética da recepção é investigar como as sentenças agem umas com as outras de maneira a criar um “todo” com a imaginação do leitor. Articulada à imaginação, a memória se transforma em peça fundamental no trabalho de leitura. "Isso é de especial importância nos textos literários”, acrescenta o teórico, "pelo fato de que eles não correspondem a nenhuma realidade objetiva para fora deles mesmos" (1990, p.276). As frases "individuais" não só trabalham juntas com o intuito de configurar uma ideia; elas "também formam uma expectativa ao olhar” (idem). Ao estabelecer relações entre "passado, presente e futuro", o leitor faz com que o texto/imagem "revele seu potencial de multiplicidade de conexões", o que se pode definir por um movimento de "retrospecção avançada” (idem). ${ }^{1}$

Afinal, não se trata de suprir a expectativa do leitor com formas prontas, mas de estimular sua contínua e perpétua “modificação” (ISER, 1990, p.278). Nas palavras do teórico:

\footnotetext{
${ }^{1}$ Esta noção se aproxima da concepção freudiana de posterioridade ou de "ação diferida", que são tentativas de tradução para o Nachträglichkeit.
} 
"O fato de que leitores completamente diferentes podem ser diferentemente afetados pela 'realidade' de um texto particular é uma evidência bastante satisfatória do grau em que textos literários transformam a leitura num processo criativo que vai além da mera percepção do que está escrito. O texto literário ativa nossas faculdades próprias, permitindo que recriemos o mundo que ele apresenta.” (idem, p.279)

Desde que consideradas as condições particulares de cada leitor, as possibilidades de leitura serão ilimitadas. Os hiatos podem ser completados das mais variadas formas. Assim, cada recepção se torna um exercício inexaurível para "realizar" a obra, já que, quanto mais fragmentário o texto, maior o esforço do espectador. O leitor "irá completar os intervalos à sua própria maneira, tal como excluirá várias outras possibilidades” (ISER, 1990, p.280). Fazer uma segunda leitura de um texto é, a esse respeito, um exemplo inequívoco: a ação poderá garantir a melhor apreensão do texto — na melhor das saídas — ou o bloqueio das especificidades que ele antes ofereceu — na pior.

Nessa medida, experimenta-se o livro como um espelho no qual se revelam elementos da experiência pessoal, embora o espectador saiba que a realidade em que vive é concretamente diferente daquela. A realidade literária, no entanto, deverá impactá-lo dependendo da extensão com a qual "ele, por si mesmo, complementa a parte não escrita do texto", ainda de acordo com Iser (1990). Ora, já não se pode dizer que, de maneira indireta, sua proposta inclui o leitor em uma experiência psicanalítica na qual ele vem a se tornar, tomadas as devidas proporções, um "analisado" do texto?

Esta é a perspectiva inaugurada por André Green: ainda que o olhar possa se perder na paisagem de traços primários do texto, a leitura flutuante - cujo procedimento se ampara na escuta em análise — faz com que unidades mínimas de sentido sejam registradas no inconsciente do espectador, sobretudo na medida em que o fascínio produzido pela obra venha a comover o leitor em seu registro consciente. Não há saída: diante da obra, o psicanalista conta apenas com o conjunto de suas próprias associações, o que implica, evidentemente, uma relação de transferência que se estabelece entre ele e o objeto de arte. Contudo, antes de ser analista, ele acaba se transformando em um analisando do texto, pois, ademais, é a obra quem o interpela e faz com que seu inconsciente se mova, suscitando um trabalho de interpretação. Dada esta condição, mais um trabalho se revela necessário: sua leitura se legitimará somente a partir do efeito que a obra leva à consciência do analista, conduzindo-o agora à posição de “crítico". Assim, o que está em jogo, de fato, é a atmosfera do que poderíamos chamar, sem mais nem menos, de experiência: na medida em que se lança ao exercício de 
recepção, o analista-espectador revela, ao fim e ao cabo, "as falhas de sua leitura e os limites de sua autoanálise”. (GREEN, 1994, p.18)²

Por outro lado, conclui Iser, “é apenas deixando para trás o mundo familiar de sua própria experiência que o leitor pode participar verdadeiramente da aventura que o texto literário lhe oferece" (1990, p.282). Só é possível ativar o trabalho da imaginação quando nos deparamos com uma ausência. Convidado a criar, o modo com o qual o sujeito dá imagem aos vazios se aproximaria do mecanismo de figurabilidade engendrado na Interpretação dos sonhos (1900/1996). Nesta retomada da Traumdeutung, o conceito representa um processo de formação imagética que interessa à reflexão estética de hoje, tal como se pode constatar em estudos do gênero (BOTELLA, 2007; DIONISIO, 2012).

A estética da recepção se afirma, portanto, como uma modalidade singular de "hermenêutica literária". Esquadrinhando as relações de tensão que habitam entre o texto e sua atualidade, o método procura as estruturas de sentido conforme mediadas pela condição histórica; com efeito, esta sua consciência da multideterminação denota um não reducionismo bastante salutar. É o que se pode verificar na introdução para Äesthetische erfahrung und literarische hermeneutik, texto-chave de Jauss que faço questão de citar:

“É só de modo parcial que a necessidade estética é manipulável, pois a produção e a reprodução da arte, mesmo sob as condições da sociedade industrial, não consegue determinar a recepção: a recepção da arte não é apenas um consumo passivo, mas sim uma atividade estética, pendente da aprovação e da recusa, e, por isso, em grande parte não sujeita ao planejamento mercadológico.”3 (1979a, p.57)

Em suma, uma das necessidades primordiais da teoria da recepção estética é produzir uma limpeza no campo ideológico. Nesse sentido, consiste em apartar, do exercício de leitura, antigos condicionamentos morais, sejam de roupagem kantiana ou luterana — no caso dos mais antigos - ou rótulos mais recentes como os do new criticism e do formalismo russo. Assim como se pode averiguar nesta passagem de "O prazer estético e as experiências fundamentais da Poiesis, Aisthesis e Katharsis”:

\footnotetext{
2 Talvez este aspecto permita que a ideia de desligamento seja também pensada em termos de pulsão de morte, como indicam Julia Kristeva (1997) e René Major (comunicação pessoal, janeiro de 2009). Para Kristeva, por exemplo, quando Freud sugere Thânatos, é exatamente disso que está falando: dé-liaison, força de retorno ao inorgânico.

${ }^{3}$ Não custa sublinhar o fato de que as publicações de pensadores como Jauss, Iser e outros se localizam temporalmente no contexto da divisão alemã, e que portanto sofreram inúmeras restrições dentro de um debate já bastante atravessado pelas ideologias, das quais a acusação de ser "alienada" não deixaria de surgir naquele momento.
} 
"A diferenciação do prazer estético realizou-se sob a necessidade de sua justificação, ante as instâncias da filosofia e da religião. Mas também a reflexão moderna sobre a conduta de prazer, que era capaz de liberar a produção e a recepção da arte, permaneceu por muito tempo subordinada a argumentação retórica e moralista." ${ }^{4}$ (JAUSS, 1979b, p.64)

Estaríamos diante de um “desejo latente” da teoria? Se o objetivo é construir, a partir do ato de expectação, os alicerces de uma leitura que ultrapassaria de uma só vez as perspectivas icônica, marxista ou estruturalista, ${ }^{5}$ a estética da recepção vem a se destacar na ordem "imanentista” do dia. Vale recordar que o contexto histórico é o da segunda metade dos anos 1970. De cada fase de hostilidade dirigida à arte, diriam os autores, a experiência estética, em sua capacidade de resistência, emerge sempre com formas novas e inesperadas, assim como as teorias que visam interpretá-la. Esquivando-se das proibições impostas por um determinado zeitgeist ou reinterpretando os cânones do passado, cabe aos artistas descobrir novos meios de expressão, e, correlativamente, de leitura.

\section{NEGAR, AFIRMAR: RECEPÇÃO E PSICANÁLISE}

Chegamos a um ponto crucial: pouco se comenta sobre o assunto, mas é fato que os teóricos não deixariam de estabelecer um diálogo com aquilo a que Jauss viria chamar um dia de “estética psicanalítica”. Se a recepção é uma práxis, tal como é a psicanálise, não se deve perder de vista que o irredutível, em ambos os casos, são os limites da percepção. Portanto, se a arte é feita para ser percepcionada, como defende Giulio Carlo Argan, não é menos verdade que seja determinada, de algum modo, no interior do Unbewussten. Mas este predicado — "inconsciente" - não interessa à Escola de Constança. No caso, Jauss identificava a teoria psicanalítica da arte à arrastada tradição aristotélica da "recepção como imitação". Para ele, mais do que colocar, no jogo das interpretações, uma anamnesis entre "técnica perfeita” e "reconhecimento perceptivo", a recepção dependeria de uma operação mental que faz com que o espectador seja afetado pela "tessitura" do trabalho. Para que a recepção venha a termo, é necessário que o receptor se

\footnotetext{
${ }^{4}$ Aqui ele se remete ao sofista Górgias, que funda a tradição retórica do "prazer pela palavra". O discurso provoca um processo, tal como a "transformação do pathos arrebatador na serenidade ética" (JAUSS, 1979b, p.67).

${ }^{5}$ Não é o objetivo aqui reconstruir uma história para a Estética da Recepção. No entanto, convém reconhecer que, conforme atesta Luiz Costa Lima (1979, p.11), existem algumas correspondências teóricas entre o grupo de Constança e o estruturalismo de Praga; também não se deve esquecer que o grupo de Constança publicaria suas teses somente algum tempo depois do grupo de Praga.
} 
identifique com os heróis ou personagens em ação, e, com isso, dê livre escoamento às suas próprias paixões através de um gozo vivido por meio da narrativa.

"O entendido de arte deseja identificar-se com o artista", escrevia, neste contexto, o influente historiador da arte Ernst Gombrich, na década de 1950; ele “precisa ser puxado para dentro do círculo encantado e partilhar seu segredo. Deve também tornar-se criativo sob a orientação do artista” (1996, p.36). Descarregando na obra um autêntico alívio espiritual, o espectador reafirma o efeito catártico provocado pela arte. À arte também restaria o papel de tela de projeções.

Ora, a catharsis aristotélica poderia ser melhor compreendida a partir do que o prazer estético exerce na conjuntura da curiosidade agostiniana: no pensamento de Santo Agostinho, o olho, enquanto órgão de sentido, nunca deixa de carregar os riscos de sucumbir ao "gozo sexual" incitado pela beleza. A constatação de que existe um tipo específico de prazer na experiência estética exigiria, em contrapartida, uma força máxima de controle espiritual; por conseguinte, serão encontrados nas formas artísticas resquícios de uma atração que corresponderiam ao fruitio (ou seja, tudo aquilo que, para Santo Agostinho, não é uti, utilizável), um desejo de saber quase "genético". Assim, o prazer com a obra seria um fenômeno influenciado pelos mecanismos de identificação e empatia (Einfühlung). Importando para o campo psicológico, neste sentido, a empatia é o que permite a existência de uma relação de transferência e, desse modo, abre espaço a uma escuta analítica propriamente dita.

Segundo Jauss:

“A catharsis, enquanto uma das funções fundamentais da experiência estética, explica (...) porque a transmissão de normas sociais pela exemplaridade da arte permite, diante do imperativo jurídico e da coerção institucional, dispor-se de uma margem de liberdade e, ao mesmo tempo, de se identificar com um modelo: o prazer catártico é tanto liberação de alguma coisa quanto para qualquer coisa. Por certo, a identificação não é por natureza um fenômeno estético. Mas os modelos heroicos, religiosos ou éticos podem ganham muito em poder sugestivo se a identificação se opera através da atitude estética. O prazer catártico faz, então — para citar Freud —, a função de atrativo (Verlockungsprämie) e pode induzir o leitor ou o espectador a assumir muito mais facilmente normas de comportamento e a se solidarizar com um herói, em suas façanhas e em seus sofrimentos.” (1991, p.62-3)

Em princípio, no entanto, a catarse seria apenas um dentre os elementos que compõem a reflexão freudiana (para não dizer psicanalítica) sobre a arte. Vejamos mais de perto: na história da psicanálise, por exemplo, representa o início do atendimento. No entanto, Freud abandonara o uso clínico da hipnose - e com isso, a utilização da catarse como ferramenta terapêutica - logo nos primeiros 
atendimentos que seguem o período charcotiano-breueriano. "Recordar e abreacionar eram, naquele tempo”, escreve de próprio punho, “as metas que se procurava alcançar com o auxílio do estado hipnótico" (FREUD, 1914/1996, p.67). Com a técnica, esperava que as resistências fossem abolidas com mais facilidade. O problema é que o alívio imediato da descarga continha, como contrapartida, uma forte tendência ao retorno: os sintomas aparentemente desapareciam, mas voltavam a se manifestar após um tempo de latência. A conclusão a que Freud é levado aparenta um tom de contradição, conquanto tenha se tornado essencial à prática clínica: é impossível fazer análise sem alguma força de resistência.

É muito comum ver não psicanalistas acusarem de "psicologistas" as saídas culturais do freudismo. Ainda que Jauss reconheça que as conquistas do campo freudiano estão além da pura vontade de "cura”, ele atribui à psicanálise a ação de sempre retificar sua teoria pelas vias da escuta clínica, ${ }^{6}$ o que demonstraria sua insuficiência em relação à contemporaneidade das obras. Com esses procedimentos de confirmação, a psicanálise negaria, a priori, todas as conquistas da estética da recepção, criada para interpretar a arte a partir de uma conjuntura que não é outra senão contextual. Para Jauss, é como se a leitura psicanalítica se resumisse à confirmação tardia de que o efeito da obra é sempre catártico e nada mais.

No meu ponto de vista, no entanto, esse argumento impede que os teóricos ultrapassem a barreira clínica, e assim demonstram seu desconhecimento quanto às questões metapsicológicas do dispositivo inaugurado por Freud. E nem seria o caso de as conhecerem. Apesar disso, quando insinuam que a dimensão intersubjetiva da experiência com a arte estaria ausente na estética psicanalítica — justamente porque se trata de uma “impossível comunicação”, segundo eles - talvez os autores se esqueçam que a psicanálise que é uma teoria elaborada a partir da clínica, de modo que privilegia um trabalho de inconsciente a inconsciente. Como ninguém, a psicanálise sabe que é possível apreender o mundo no que ele é pré-consciente e pré-verbal. A rigor, portanto, a práxis analítica fornece provas de que não haveria uma suposta "incomunicabilidade". A possibilidade de se pensar a existência de um inconsciente não significa atribuir uma carga fechada de determinações no oposto, ou seja, “que o prazer estético se relaciona com o passado, com o retorno do recalcado" (1979b, p.70). Nessas circunstâncias, é como se a psicanálise da recepção se limitasse a condições genealógicas que fatalmente se esgotam no famigerado Complexo de Édipo.

Mas não parece ser esse o caso, e a história recente das análises direcionadas a obras de arte não permite associações como essas (FELMAN, 1992; FOSTER,

\footnotetext{
${ }^{6}$ Essa ressalva se aproxima em muito do que pensava Karl Krauss a respeito da psicanálise como um todo: Krauss acusava a psicanálise de "curar as doenças que ela mesma inventava". No entanto, a confirmação da teoria pela clínica é um traço inexorável à psicanálise, sendo ela aplicada ou não; sem isso, perde-se de vista sua ética.
} 
1996; DIDIER-WEILL, 2005). Freud, de sua parte, não analisa apenas Hamlet, cujo conteúdo vem, de fato, quase pronto para uma psicanálise; no conjunto da obra de Shakespeare, ele também se concentrou, por exemplo, no Mercador de Veneza, e isso conforme uma investigação bastante minuciosa acerca da psicologia do espectador, assim como se pode notar da primeira à última linha de "O motivo da eleição do cofre”, escrito por ele em 1913, isto é, entre o texto sobre Leonardo e o artigo não assinado sobre o Moises de Michelangelo (FREUD, 1913/1996, p.303).

A exemplo do que fizeram os psicólogos do ego — ou seja, uma escola reconhecidamente americana — os colaboradores da estética da recepção também se debruçaram sobre os fenômenos da fantasia e da ilusão, contexto em que Sartre se tornaria um personagem importante. De acordo com Iser, se a recepção pressupõe relações dialéticas entre sujeito e objeto, isso também implica reconhecer que aí se encontra um "prazer de si no prazer do outro" (é uma expressão) conforme foi elaborado pelo filósofo francês. A ilusão é o seu exercício: o princípio da identificação ao herói funciona como uma "necessidade antropológica" capaz de assegurar um prazer que, combinado ao alívio por não ser o próprio indivíduo sujeito às ações da narrativa, distancia e protege o receptor. Ao se deparar com a obra ele acessará certas quantidades de investimento psíquico ligadas ao conteúdo fantasístico, o que lhe garante uma autoproteção contra a dor. Consequentemente, a capa protetora possibilita um "gozo de desrecalque" frente à cena contemplada, pois ela seria vivida, no presente momento, em seu mundo interno. ${ }^{7}$ Eureca: o prazer de si no outro prevê a possibilidade de se participar ao mesmo tempo de dentro $e$ de fora da cena. Uma vez que o psiquismo consiga se lançar, pela via das projeções, ao âmago da alteridade dos personagens - o herói, o vilão, a donzela - o espectador conseguirá vivenciar a experiência estética como fonte de satisfação.

Com isso, Jauss consegue enxergar algo mais que uma simples retomada da teoria aristotélica, concluindo que "a teoria da Freud sobre o autoprazer estético no prazer no outro não se esgota em uma reprise psicanalítica da catarse" (LIMA, 1979, p.35). Este ponto é, com efeito, crucial: sua reflexão avança na medida em que o esteta percebe um "princípio de prazer" subjacente à recepção. Pressentindo a insuficiência da proposta aristotélica, o autor considera que aquilo

\footnotetext{
${ }^{7}$ Essas considerações se articulam ao que Bazin escreveria no capítulo dedicado à psicanálise dentro de História da história da arte: "Para Freud, a arte é o produto do desejo (libido), não por um jorro direto, mas pelo caminho tortuoso da compensação a um recalque desse desejo imposto pela sociedade que se interpõe entre o criador e sua obra. A alma só se manifesta nessa água turva da neurose, da qual, entretanto, Freud, que é um romântico, dispensa certos gênios, admitidos a abeberar-se da fonte pura". O historiador rejeita, em outros termos, a ideia de uma "estética psicanalítica": "Recorrer automaticamente à sexualidade, como o faz Freud", acrescenta, "para encontrar as fontes da criação é afastar-se de suas verdadeiras causas” (1989, p.270-1).
} 
“que a doutrina tradicional do prazer catártico incluía é atualizado por Freud e, ao mesmo tempo, superado pela nova descoberta, segundo a qual, ao puro ganho de prazer estético na economia psíquica, se acrescenta uma função mais ampla — a de um prazer primário ou de uma ‘bonificação de incentivo' (Verlockungsprämie) para a 'liberação de um maior prazer advindo de fontes mais profundas.”. (JAUSS, 1979b, p.79)

De sua parte, no entanto, Freud jamais negara a presença da ilusão na experiência com a arte, e os limites da compreensão psicanalítica de Iser e Jauss não escaparam a Luiz Costa Lima, tal como se depreende em $A$ literatura e o leitor: textos de estética da recepção (1979), coletânea inaugural publicada no Brasil. "Ora”, argumenta em favor do médico vienense, diante do idealismo disfarçado nos textos dos pesquisadores de Constança, “a reconsideração do Freud mais sério parece inestimável para uma teoria da literatura que não mais se delicie com a subversão do poético". Contudo, é isto, precisamente, o que acaba sendo deixado de lado. Iser, por exemplo, esquematiza tanto em sua teorização a ponto de manifestar uma vontade de estipular certos "tipos ideais" de leitor.

Por outro lado, também chega perto de perceber a dimensão do vazio que qualquer texto - e em especial, os escritos ficcionais - tem por mérito trazer à tona, um vazio que, em outras palavras, pode ser traduzido pela influência que os processos inconscientes exercem tanto na leitura quanto na produção de arte. E o que mais pode fazer um psicanalista, senão revelar os hiatos do discurso de seu paciente? "Isso para não falar de uma teoria que se querendo do ficcional — i.e., que não o tome apenas como um elemento a integrar na historiografia social, já não se limite ao circuito fechado de experiência e análise estéticas” (LIMA, 1979, p.36).

Se o texto, enquanto Gestalt, oferece ou motiva um repertório de projeções e identificações do leitor, e se esse espectador deve se comportar sempre como um estrangeiro diante da obra, então é inerente ao objeto "concentrar-se nos vazios comuns a todas as relações humanas, explorá-los, torná-los sistemáticos”. Se proceder deste modo, é provável que espectador venha a descobrir o "papel que o inconsciente desempenha na caracterização dos textos ficcionais como estratégias de articulação de vazios” (p.24-36), como os autores virão a concluir mais tarde.

Em relação à psicanálise do intérprete, as ideias de Iser e Jauss parecem se concentrar, mais especificamente, em "Escritores criativos e devaneio", texto no qual Freud se refere ao poeta como um ser dotado da habilidade de seduzir o outro por meio de uma "vontade puramente formal, quer dizer, estética, que nos brinda com a figuração de suas fantasias” (FREUD, 1908/1996, p.135, grifos meus; GAY, 1989, p.288). De acordo com o Freud daquela época, a vontade formal induz ao desprendimento cada vez maior de cargas de prazer, sendo 
que a forma perfaz o lugar onde residem as experiências vividas como prêmio de sedução ou de prazer prévio. Mais uma vez, a teoria conduz à antiga tese da liberação catártica, sobretudo quando lemos, em uma passagem do próprio Freud, que:

“todo prazer estético que o poeta nos oferece leva em conta o caráter desse prazer prévio, e que o gozo genuíno da obra poética advém da liberação de tensões no interior de nossa alma. Acaso contribui a este resultado, ainda que em menor medida, que o poeta nos habilite a gozar na sucessão sem culpa ou vergonha de nossas próprias fantasias". (1908/1996, p.135)

Os desejos insatisfeitos são expressão e motor pulsional das fantasias, e estas, seguindo esta lógica, são retificações de um desejo que permanece insatisfeito; em dado momento, o prazer estético oportuniza uma nova possibilidade de satisfação àquele desejo reprimido. Neste Freud, a temporalidade da satisfação não ocorre de maneira linear: as catexias saem do presente e recorrem ao passado, para só então se lançarem ao futuro. A partir de uma vivência atual, o poeta produziria uma regressão a lembranças anteriores (infantis), levando-as a se projetar em um futuro mais próximo de realização e, neste caso, pela via do formal. A situação atual faz com que se anime uma anterior; a circunstância cria uma aliança com o desejo que, por sua vez, retroalimenta a invenção poética. Já o desejo, como se sabe, carrega marcas passadas e procura novos objetos de realização.

Se nos debruçarmos nas intervenções de Jean-François Lyotard, delineadas neste caso em Dérive à partir de Marx et Freud (1975), podemos compreender o quanto a dimensão catártica, ainda que inseparável da experiência estética, não representa somente um obstáculo ao entendimento da recepção psicanalítica. A catarse forneceria, nesta perspectiva, pistas adequadas para a interpretação de poéticas modernas. Uma vez que se encontra, dentre suas principais características, uma abertura do olhar "sem imposições [,] em que poderiam deixar-se ver as operações que formam as figuras mais profundas” (LYOTARD, 1975, p.10), ela permitiria surgir uma expressão que "condensa”, por assim dizer, o espírito da modernidade. Com isso, o próprio papel da tragédia edípica deixa de ser um mero exercício de ilustração ou de aplicação para assumir uma posição que designaria relações complexas de encontro e reconhecimento no interior do dispositivo freudiano.

E conforme a história de Édipo foi sendo transformada em "romance das origens", romance ao qual estaríamos todos psicologicamente assujeitados, Marthe Robert considera que:

“esse romance das origens não revela apenas as origens psíquicas do gênero aquém dos acidentes individuais e históricos de onde brota incessantemente uma obra singular: ele é o próprio gênero com suas virtualidades inesgotáveis e seu infan- 
tilismo congênito, o gênero falso, frívolo, grandioso, mesquinho, subversivo e maledicente de que todo homem é efetivamente filho (...), mas que devolve também a todo homem algo de sua primeira paixão e sua primeira verdade”. (2007, p.49)

\section{MUITO ALÉM DE ÉDIPO}

André Green discutiu implicações desta ordem, embora com resultados contrários, em Un œil en trop (1981): ao analisar minuciosamente a função que o Édipo ganhou na teoria freudiana, Green entendia que já ali não se pode encontrar uma suposta reconciliação de polos psíquicos opostos. O que restaria de Édipo, afinal?, pergunta-se: uma historieta que ri do edifício psicanalítico? Não, de modo algum: diante da peça de Sófocles, o espectador conseguiria vislumbrar apenas um desconhecimento - tese com a qual Jacques Rancière provavelmente concordaria, a nos basearmos em seu Inconsciente estético (2009).

A vulgata que por vezes se associa ao Édipo freudiano só ganha força quando sua estrutura psíquica se vê descontextualizada, quer dizer, retirada de sua função subjetivante. Por ora, só compreendemos que o Édipo Rei traduz uma expressão trágica porque a obra põe em jogo uma determinada verdade (inconsciente), que é a das equivalências simbólicas entre a cena trágica e a cena psicanalítica. "A dupla norma que obriga de um lado ao sujeito a praticar a livre associação, e de outro ao analista a prestar aos dizeres do paciente uma 'atenção igualmente flutuante", , lê-se no ensaio de Lyotard, "não equivale a ter aberta, livre de obrigações secundárias, uma região de onde as formas figurais poderão manifestar sua presença?”. E assim finaliza: “Uma vez aberta esta área, a diferença entre a arte e a análise não é, quiçá, mais ampla que a que separa o desejo de ver daquele de dizê-lo". (1975, p.77)

Voltando ao problema da recepção propriamente dita, talvez o entendimento do prazer estético como retorno do recalcado seja a resposta mais coerente que a estética da recepção pôde encontrar em sua leitura de Freud. Se se sublinha, no seguinte trecho: "desde que se entenda que este prazer é determinado pela distância interior do eu, que se faz estranho a si próprio, e a superação (Aufhebung) desta distância em uma catarse que brota do prazer do trabalho e da relembrança” (JAUSS, 1979b, p.79), os significados fortes de trabalho e relembrança, pode-se compreender com maior nitidez as conclusões a que chegaram os teóricos de Constança. Trabalho e lembrança são, com efeito, operações psíquicas privilegiadas pela atitude analítica receptiva, mas não conseguem dar conta deste processo complexo que se estabelece entre espectador e obra de arte. Contudo - e isto justificaria, por si só, a posição dos teóricos alemães — é fato que muitos psicanalistas desavisados pressupõem que o recalcamento seja o dínamo privilegiado de produção de imagens, aqui incluídas as que são consideradas artísticas. 
Para Wolfgang Iser, tratando-se ou não de um retorno do recalcado, o que está em jogo é a figuração (picturing) pela qual a imaginação constrói imagens no decorrer da leitura. Segundo ele, esta figuração é apenas "uma das atividades por meio das quais formamos a 'gestalt' do texto literário” (1990, p.283). Não há dúvida de que toda forma necessite de um mínimo de organização para se tornar perceptível; porém, essa gestalt não indica o verdadeiro sentido do texto porque, "na melhor das hipóteses", escreve Iser, ela é somente "uma compreensão configurativa”. "Com o texto literário, esta compreensão é inseparável das expectativas do leitor", e, assim como existem expectativas, tem-se "uma das mais potentes armas do repertório do escritor — a ilusão” (1990, p.284).

Sua árdua procura por verdades cognitivas, somada à vontade de impor padrões textuais inteligíveis que determinariam a leitura, impede que a psicanálise tenha aí um lugar ao sol. Neste método de interpretação, "com certeza discrepâncias surgirão. Elas são o lado reverso da moeda interpretativa, um produto involuntário do processo que cria discrepâncias ao tentar evitá-las” (ISER, 1990, p.290). Mas esta confusão que acomete o leitor é mesmo indispensável a qualquer atividade de leitura, já que provoca o anseio de refletir sobre o experienciado, sendo talvez esta "a principal função da crítica literária”. Auxiliando “tornar conscientes aqueles aspectos do texto que de outro modo permaneceriam subconscientes", a reflexão estética "satisfaz (ou ajuda a satisfazer) nosso desejo de falar sobre o que foi lido". Assim, se esta "urgência” remete-se a um “evento vivo” (p.290) e, portanto, sempre aberto, então ela acaba obrigando o leitor a procurar por cada vez maior consistência, na tentativa de compreender aquilo que, durante a leitura, não lhe soa familiar.

Em suma, de acordo com o autor, ler significa suspender "as ideias e as atitudes que moldam nossa própria personalidade”. Contudo, ao fazê-lo o sujeito procura absorver esse não familiar, utilizando-se do mecanismo de identificação, assim deixando borrar as fronteiras entre o eu e o outro:

“Geralmente o termo identificação é usado como se fosse uma explanação, embora seja de fato nada mais que uma descrição. O que é normalmente designado por 'identificação' é o estabelecimento de afinidades entre um e outro — um terreno familiar no qual nos sentimos aptos a experimentar o não familiar. A meta do autor, assim, é provocar a experiência e, sobretudo, uma atitude quanto a ela. Consequentemente, a 'identificação’ não é um fim em si mesmo, mas uma estratégia pela qual o autor estimula atitudes no leitor.” (ISER, 1990, p.291)

Identificação, é sabido, foi desde sempre um conceito caro à psicanálise. $\mathrm{Na}$ doutrina de Lacan, nesta medida, chega a depender de uma alienação primordial com a qual o humano edifica seu registro imaginário - e, por conseguinte, 
o simbólico e o real. Se o princípio de prazer se regula apenas quando evita o desprazer, o alívio pode surgir de satisfações que vêm tanto de fora para dentro quanto de dentro para fora, de acordo com o funcionamento dialético (e inseparável) dos mecanismos de identificação e projeção.

$\mathrm{Na}$ esteira de Georges Pulet, Iser considera que o processo de se identificar, puramente descritivo, depende de dois elementos: (1) "a história de vida do autor deve ser excluída do trabalho", assim como (2) "a disposição individual do leitor" deveria sê-lo "do ato de ler" (1990, p.292-3). Deste modo, o texto pode ser considerado "uma consciência em si", de tal maneira que os pensamentos do autor acabam tomando um lugar subjetivo no leitor. Com isso a divisão entre texto e audiência não será mais externa, e vêm a se localizar no interior da vida mental do espectador. "Quando lemos", completa o filósofo, "ocorre uma divisão artificial de nossa personalidade, porque tomamos como tema, para nós, algo que na verdade não somos". (ISER, 1990, p.293)

Mas a questão não para por aí. É impossível dizer que a interpretação que os teóricos da recepção estética fizeram de Freud seja tão-somente uma redução: Iser, por exemplo, sabe o quanto a experiência de recepção está intimamente ligada à capacidade que o ser humano tem de desejar, assim como o ato de recepção demanda todo um circuito de implicações subjetivas. Ao "ter que pensar a respeito de algo que nunca experienciamos", escreve a este respeito, "não significa que se está apenas numa posição de concebê-lo ou mesmo de entendê-lo"; para o autor, "isso também significa que tais atos de concepção são possíveis e bem-sucedidos no nível em que conduzem a algo que é formulado em nós”. Em outras palavras, o trabalho de leitura exige que o leitor reformule sua própria capacidade de decifração, pois ali "trazemos à tona um elemento de nosso ser em relação ao qual não nos encontramos diretamente conscientes” (1990, p.294, grifos meus) — é o que Iser propõe em seus artigos mais maduros. Tal como se dá em uma relação analítica, as possibilidades de transformação de si não podem ser excluídas do horizonte de realização da ação receptiva.

Recebido em 6/10/2010. Aprovado em 13/9/2011.

\section{REFERÊNCIAS}

BAZIN, G. (1989) História da história da arte: de Vasari a nossos dias. São Paulo: Martins Fontes.

BOTELLA, C. \& BOTELLA, S. (2007) La figurabilité psychique. Paris: In Press. DIDIER-WEILL, A. (2005) Invocações: Dionísio, Moises, São Paulo e Freud. Rio de Janeiro: Companhia de Freud. 
DIONISIO, G. H. (2012) Pede-se abrir os olhos. Psicanálise e reflexão estética hoje. São Paulo: Annablume/Fapesp.

FELMAN, S. (1992) Literature and psychoanalysis: the question of reading, otherwise. New Haven: Yale French Studies.

FOSTER, H. (1996) The return of the real: the avant-garde at the end of the century. Cambridge: MIT Press.

FREUD, S. (1996) Obras completas. Buenos Aires: Amorrortu. (1900) “La interpretación de los sueños”, v.IV, p.345-355.

(1908) “El creador literario y el fantaseo”, v.IX, p.123-136.

(1913) “El motivo de la elección del cofre”, v.XII, p.303-318.

(1914) “El Moises de Miguel Angel”, v.XIII, p.213-242.

GAY, P. (1989) Freud: uma vida para nosso tempo. São Paulo: Companhia das Letras.

GOMBRICH, E. (1999) Meditações sobre um cavalinho de pau e outros ensaios sobre a teoria da arte. São Paulo: Edusp.

GREEN, A. (1969) Un œil en trop: le complexe d'œedipe dans la tragédie. Paris: Les Éditions de Minuit.

(1994) O desligamento: psicanálise, antropologia e literatura. Rio de Janeiro: Imago.

ISER, W. (1979) “A interação do texto com o leitor”, in LIMA, L. C. (1979) A literatura e o leitor: textos de estética da recepção. Rio de Janeiro: Paz e Terra. Press.

(1990) The implied reader. Baltimore: John Hopkins University

JAUSS, H. R. (1979a) “A estética da recepção: colocações gerais”, in LIMA, L. C. (1979). A literatura e o leitor: textos de estética da recepção. Rio de Janeiro: Paz e Terra.

(1979b) "O prazer estético e as experiências fundamentais da Poiesis, Aisthesis e Katharsis”, in (1991) Pour une esthétique de la réception. Paris: Gallimard.

LIMA, L. C. (1979) A literatura e o leitor: textos de estética da recepção. Rio de Janeiro: Paz e Terra.

KRISTEVA, J. (1997) Pouvoirs et limites de la psychanalyse II: La révolte intime. Paris: Fayard.

LIMA, L. C. (1979) A literatura e o leitor: textos de estética da recepção. Rio de Janeiro: Paz e Terra.

LYOTARD, J-F. (1975) A partir de Marx y Freud. Madrid: Fundamentos.

ROBERT, M. (2007) Romance das origens, origens do romance. São Paulo: CosacNaïfy.

STAROBINSKI, J. (2008) La relation critique. Paris: Gallimard. 